\title{
DAS RESISTÊNCIAS AO ENSINO ESCOLAR DE HISTÓRIA DA ÁFRICA: \\ ALGUMAS CONSIDERAÇÕES
}

\section{RESISTANCE OF THE HISTORY OF SCHOOL EDUCATION IN AFRICA: SOME CONSIDERATIONS}

\author{
José Henrique Rollo Gonçalves ${ }^{1}$ \\ Para Ana Lucia Silva e Sonia Ortiz, \\ professoras dignas e indignadas.
}

\begin{abstract}
RESUMO: O artigo discute certas atitudes de repúdio mais ou menos ostensivo à introdução de conteúdos relativos à história africana em todos os níveis de ensino no Brasil. Ele sugere que não se trata somente, como sustenta uma voz corrente, de falta de informações básicas neste país sobre a África. Tampouco de falta de empenho das autoridades que devem zelar pela efetivação das propostas de inovação curricular. As razões são mais amplas. Elas têm raízes profundas nas mentalidades coletivas, especialmente na forte vigência de crenças e valores ocidentocêntricos. Também tem a ver com o evolucionismo intrínseco às Teorias da História predominantemente ensinadas nos cursos universitários.
\end{abstract}

Palavras-Chave: História da África. Ocidentocentrismo. Ensino escolar. História e Cultura Afro-Brasileira.

\begin{abstract}
The article discusses certain dismissive attitudes about the introduction of ostensible subjects related to African history at all levels of education in Brazil. He suggests that it is not only, as it maintains a current voice, lack of basic information in this country on Africa. Nor the lack of commitment of the authorities must ensure the effectiveness of the proposed curriculum innovation. The reasons are broader. They have deep roots in the collective mentality, especially in the presence of strong beliefs and values occidental centralism. It also has to do with the intrinsic theories predominantly evolutionism taught history at the college level.
\end{abstract}

KEYWORDS: History of Africa. Occidental centralism. School education. History and Afro-Brazilian Culture.

\footnotetext{
1 Doutorado em História Comparada pela Universidade Federal do Rio de Janeiro (2013). É professor junto aos Cursos de Comunicação e Multimeios e de História na Universidade Estadual de Maringá.
} 
No dia 27 de outubro de 2008, um dos mais influentes jornais do país informou que, "depois de cinco anos e mais de $R \$ 10$ milhões gastos com capacitação de professores, a lei federal que obriga escolas públicas e particulares de todo o país a ensinar história e cultura afro-brasileira - uma das primeiras medidas do governo Lula - não saiu do papel". Expressamente mencionada, a então coordenadora-geral de Diversidade e Inclusão do Ministério da Educação reconheceu que, no processo de implementação da lei 10.639 (de janeiro de 2003), "não houve um planejamento. Só algumas escolas públicas, em razão de professores interessados, adotaram a lei. As particulares nem sequer discutiram a temática". Para solucionar o problema, prometia-se tomar medidas capazes de fazer com que a determinação legal deixasse de ser uma "iniciativa individual para se tornar institucional". Infelizmente, o jornal não listou que atitudes seriam tomadas pelas autoridades educacionais. Apenas complementou o informe observando que, na Bahia, em 2007, o Ministério Público instaurou inquérito civil e notificou as escolas exigindo o cumprimento da lei. (ACAYABA e REIS, 2008). Notícias como essas são deveras preocupantes, mas não são surpreendentes. De lá para cá, a imprensa nacional pouco voltou ao assunto, embora a situação descrita tenha ficado mais inquietante e complexa, já que agregou, agora, um novo dispositivo institucional, a lei 11.645 (março de 2008), que, aprofundando as determinações anteriores, tornou obrigatório o ensino escolar da temática indígena. Tal situação contrasta vivamente com as profundas expectativas que precederam e que se seguiram ao decreto presidencial de janeiro de 2003. Naquela época, os meios de comunicação veicularam as principais posições em disputa, mostrando que havia um forte debate em curso, nada sugerindo que, passados alguns poucos anos, o assunto ficaria praticamente resumido à condição de mais um problema espinhoso que atribula o universo escolar.

Enfim, apesar da vasta quantidade de materiais publicados a respeito (dos quais vários estão disponíveis na Internet) e das diversas ações didáticopedagógicas desde então realizadas, muitas dúvidas, polêmicas e resistências ainda cercam, vários anos depois de sua assinatura, a determinação federal que 
torna "obrigatório o ensino sobre História e Cultura Afro-Brasileira" nas escolas de todo o País. Estaríamos diante de mais uma dessas famigeradas leis que não pegam? Não creio que tem cabimento dar força para esse tipo de diagnóstico conformista e debochado. Porém, não tenho a menor dúvida de que essa é a esperança de muita gente que, por diversas razões - que variam do preconceito ao desinteresse, passando pelo prazer de aboletar-se na inércia e pela simples, mas, muitas vezes, igualmente prazerosa, estupidez - não quer que essa iniciativa vá para frente. Nesta conexão, proponho nestas páginas algumas idéias para se discutir uma face da questão, qual seja, alguns dos entendimentos possíveis dos termos da lei, em particular no que tange à História da África propriamente dita. Parto da hipótese de que boa parte das dúvidas generalizadas e das resistências mais ou menos ativas dos professores em lecionarem o tema decorre da forma hegemônica - portanto, presente em concepções teóricometodológicas diferentes (e até contrapostas) - de se entender a História seja como relato, seja como conjuntos de ocorrências do passado.

Ao tempo em que as novas determinações educacionais vieram a lume, em 2003, já se acumulara um bom par de décadas de mobilizações pela introdução de conteúdos sobre a África e as diásporas africanas nos programas escolares brasileiros. (cf. ROCHA, 2007; SILVA, 2010). Vinte anos antes, o deputado federal Abdias do Nascimento propusera um vasto leque de temas afins que deveriam ser ensinados às crianças e adolescentes, mormente, as negras. Segundo ele, quando chegam a ter a oportunidade de estudar, os jovens afro-descendentes ficam expostos a um conteúdo programático que constitui "outro aspecto da desigualdade racial anticonstitucional na esfera da educação". Isso porque

a civilização e história dos povos africanos, dos quais descendem as crianças negras, estão ausentes do currículo escolar. A criança negra aprende apenas que seus avôs foram escravos; as realizações tecnológicas e culturais africanas, sobretudo nos períodos anteriores à invasão e colonização européia da África, são omitidas (apud SILVA, COSTA e MINDAL, 2007, p. 12-13). 
Pela mesma época, o historiador gaúcho Decio Freitas chamara a atenção para o fato de que, apesar de os africanos terem se constituído no "maior contingente imigratório recebido pelo país", a história daquele continente "não só não consta dos programas de ensino, como em geral sequer é conhecida entre os letrados" (FREITAS, 1982).

As intervenções em favor do ensino e do estudo de História da África remontavam a momentos ainda mais distantes. No agora longínquo ano de 1965, por exemplo, Johildo Lopes de Athayde, então professor da UFBA, abriu um curso a respeito da África Negra Pré-Colonial em Salvador denunciando aqueles que, alegando que a luta anti-colonialista no continente era "orientada por interesses externos", acreditavam que

...constituem um absurdo reivindicações de autenticidade, de respeito, de autonomia, por parte de uma África Negra vazia de passado, indiferente às coisas da civilização e condenada, pelo seu primitivismo, a se arrastar de pés cortados pelos caminhos da História (ATHAYDE, 1965, p. 57).

Para ele, que se pronunciava bem no calor dos processos de formação dos Estados modernos do continente, cabia ao historiador "uma participação nas lutas, pois ele também, ao lado dos demais, constitui-se em legítimo operário do presente". (ATHAYDE, 1965, p. 57). Tais palavras ajudam a por em perspectiva a força dramática do fato ocorrido na capital baiana mencionado no primeiro parágrafo. Depois de décadas de cursos de introdução ao estudo da África e de programas de especialização promovidos pela UFBA, aos quais se poderiam acrescentar as iniciativas similares dos membros do Centro de Estudos AfroAsiáticos (CEAA/Universidade Cândido Mendes) do Rio de Janeiro, os resultados em termos de formação docente em todos os níveis continuam terrivelmente pequenos.

Convém lembrar que, do outro lado do front, também se empilhara um grande número de manifestações contrárias que retrocediam - para se dar uma data mínima - aos debates travados quando das celebrações dos 100 anos da Lei Áurea, em 1988. Na época, foi possível encontrar pessoas como o jornalista João Carlos Rodrigues, que enxergou entusiasmado uma 
...curiosidade crescente pelo tema, [que] já se reflete na obrigatoriedade do ensino de assuntos africanos incluída na constituição de alguns Estados da federação, assim como no renascimento dos afoxés e blocos afros do carnaval de Salvador (que tinham deixado de existir no final dos anos 30) (RODRIGUES, 1990, p. 9).

Porém, pouca coisa realmente eficaz se fez na ocasião. Autoridades educacionais de algumas unidades da federação chegaram a cogitar de introduzir conteúdos de história africana nos programas escolares, mas tudo ficou na promessa. De fato, predominava a opinião pela cautela e por uma ação bastante gradual, sob o pretexto de que os recursos bibliográficos disponíveis para uma formação didático-pedagógica pelo menos razoável na área eram precários (cf. ALENCASTRO, 2001).

Houve, do mesmo modo, quem associasse tais demandas a fatores deletérios, como, para lembrar o mais evocado, a presumível influência de questões típicas dos afro-estadunidenses que, alegava-se, tinham pouco a ver com a vida brasileira. Nessa linha de raciocínio, algumas pessoas mostravam-se preocupadas, por exemplo, com a importação de modos de entender as diferenças étnico-raciais que, embora fossem pertinentes aos Estados Unidos e a alguns países caribenhos, não se encaixavam, de acordo com a ideologia dominante, na história pátria. Reiterando uma preocupação que já se fizera presente durante o regime militar, temia-se que a escola acabasse por criar ou estimular os conflitos raciais em um país que se acreditava ser um modelo de resolução conciliadora das diferenças entre grupos, classes e raças (MOURA, 1988; PELLEGRINI e ALVES, 2011). Na prática, tanto pelo sucesso das pressões contrárias, quanto pela falta de um consenso mínimo acerca do que deveria ser priorizado no encaminhamento do processo, as coisas não deram em nada.

Um dado permanente de todas essas discussões era a tímida presença de pronunciamentos qualificados e autorizados provenientes dos meios acadêmicos. Uma das razões mais evidentes disso era ( $\mathrm{e}$, infelizmente, ainda é) a pouca importância dada ao tema nos processos de formação da historiografia e de consolidação das atividades de ensino e pesquisa históricas entre nós. No começo da década de 1980, quando o assunto criou asas e deu seus primeiros e tímidos vôos, contavam-se nos dedos de uma só mão os profissionais universitários brasileiros que trabalhavam regularmente com a história africana. 
Raramente se publicava ou ensinava algo que não tivesse a ver com os antecedentes imediatos do comércio negreiro. Noutras palavras: quando se falava da África era em função da história da diáspora ou, mais propriamente, da história dos países para os quais foram levados escravos africanos. O continente em si mesmo continuava praticamente destituído de interesse para os brasileiros (e, mais amplamente, para os latino-americanos) (cf. ROMERO, 1972). Nos compêndios escolares, salvo a extraordinária exceção que foi o manual dos professores Francisco Falcon, Maria Alice de Carvalho, Selma Rinaldi de Mattos e Ilmar Rohloff de Mattos, lançado em 1977, que dedicava um capítulo assessorado por José Maria Nunes Pereira - aos impérios do Sudão Ocidental e aos povos do litoral atlântico, reinava o silêncio absoluto. (FALCON et alli, 1977, p. 37-51). Em suma, os intelectuais falavam contra ou a favor, mas na maioria das vezes de fora do assunto.

Paralelamente, no decorrer das décadas de 1980 e 1990, diversos grupos de ativistas afro-descendentes mais ou menos institucionalizados dedicaram-se à elaboração e disseminação de cursos de treinamento básico e a produção de materiais didáticos relacionados a questões africanas e afro-americanas voltadas para professores do ensino fundamental e médio (ver LIMA, 2008). Suspeito mas não fiz uma investigação para verificar essa possibilidade - que a opinião crítica formada por tais iniciativas tenha sido decisiva na composição das coligações, das frações intra-partidárias, dos segmentos burocráticos e dos grupos de pressão que obtiveram como sucesso parcial a aprovação da lei 10.639, em janeiro de 2003. Também tenho a impressão - que precisaria, do mesmo modo, ser comprovada por uma pesquisa empírica - de que o êxito dessas ações ocorreu a despeito das elites dominantes nos meios acadêmicos, que não deram muita bola para o assunto, como se pode notar pela magreza dos artigos a seu respeito nas revistas consagradas (ou seja, mais pontuadas pelos critérios meritocráticos vigentes). Se essas sugestões estiverem certas, as coisas ficam particularmente interessantes ao se considerar a conjuntura mais vasta em se deram as mobilizações em favor da obrigatoriedade de conteúdos africanos e afro-brasileiros nos programas escolares. Elas cresceram na época em que era mais intensa a defesa ostensiva via meios de comunicação de massas da ideologia do choque de civilizações e seu corolário (que, patética e 
tautologicamente, também é sua premissa): a crença na unidade e na superioridade do Ocidente.

Neste momento, não posso entrar a fundo nessa questão. Por isso, limitome a pontuar alguns fatores que considero fundamentais. $O$ alvo principal dessa invectiva é tudo aquilo que for identificado, independente da auto-percepção dos envolvidos, como proposta ou ação de cunho multiculturalista. Nas décadas de passagem de um século a outro, já não era mais o caso de combater os velhos inimigos comunistas, que estavam a desmoronar e a transitar para a órbita moral, econômica e política do assim-chamado Mundo Livre. Agora, é o caso de atacar tudo o que for considerado, tenha ou não essa intenção manifesta, como uma conspiração contra o Ocidente. E quem são os novos guerreiros? Em sua maioria, não são mais do que velhos falcões que aprenderam (ou criaram) um novo vocabulário. Não é preciso dar nomes, apenas falar de disposições intelectuais e emocionais. Os combatentes de hoje em dia são pessoas que continuam defendendo, como na Era da Guerra Fria, um conjunto de crenças, valores e propostas de organização da sociedade que pressupõem, entre outros aspectos, uma economia centrada nas leis do mercado com uma redução drástica da ação do Estado sobre ela, a idéia de competição eleitoral pluripartidária como o supra-sumo da participação política das massas e a crença na superioridade teológica e ética das igrejas ou denominações cristãs sobre as demais religiões (p. ex., HARRISON e HUNTINGTON, 2002).

Ao mesmo tempo em que a ideologia do choque de civilizações tornou-se um componente cada vez mais determinante das certezas coletivas compartilhadas pelas elites dirigentes ocidentais, cresceram as agressões aos povos do que antes era chamado de Terceiro Mundo. Agora, porém, já não se justificam as intervenções em nome da prevenção contra o avanço comunista, mas por duas alegações básicas. Primeira: para livrar povos indefesos dos ditadores que os massacram, como se pretendeu fazer no Iraque e, nos dias em que escrevo este artigo, se quer fazer na Líbia. Segunda: para exterminar os inimigos fundamentalistas do Ocidente. Ademais, uma terceira alegação expande-se a galope pelas mídias internacionais: a necessidade de proteger certos povos de si mesmos, ou seja, dos péssimos dirigentes que eles botam no poder, de suas ações devastadoras do ambiente, de suas guerras intermináveis, 
de suas epidemias incontroláveis, de seu desperdício de recursos naturais, financeiros e humanos. Noutras palavras, apregoam-se as intervenções humanitárias ou o imperialismo bem-intencionado. Neste último caso, o alvo prioritário são os países da África (cf. KLARE, 2003). Acrescente-se a esses fatores o vigor de uma idéia, que sempre contou com forte legitimação em certas searas acadêmicas, de que a natureza ingrata e inóspita encapsulou as sociedades africanas, desfavorecendo o avanço econômico e sustentando o fatalismo e os vetores de resistência à mudança.

Vale a pena discorrer um pouco sobre esse último ponto. Como se sabe, o determinismo ambiental não é algo recente. Já na Grécia Antiga havia os que a ele creditavam as diferenças entre os povos e até a causa de algumas moléstias (TOYNBEE, 1959, p. 72 e ss). Mas foi no começo do século XX que os adeptos desse tipo de explicação histórica (no fundo, ahistórica) vicejaram amplamente. Eles se beneficiaram dos avanços das ciências naturais, que lhes forneciam um vocabulário tido por respeitável e preciso (logo, dotado de presumida superioridade cognitiva), e da grande quantidade de relatos de exploradores, missionários, burocratas e militares colonialistas que inundavam as livrarias européias e norte-americanas. Uma verdadeira roda viva ideológica: premissas deterministas alimentavam as narrativas sobre os povos não-ocidentais e reforçavam as teorizações deterministas de gabinete que, por sua vez, retroalimentavam aqueles relatos e assim por diante. Entre as décadas de 1930 e 1950, tanto essas idéias quanto suas primas, as teorias raciológicas, foram submetidas a um profundo escrutínio por antropólogos preocupados em enfatizar a força causal e diferencial da cultura (em contraposição à natureza = ordem biológica) e por sociólogos que buscavam demarcar um âmbito analítico autoexplicativo - a sociedade - dotado de propriedades imanentes. Ambos os vetores críticos foram reforçados pelo repúdio ao racismo dos nazifascistas e seus admiradores (cf. MERCIER, 1974; POIRIER, 1981).

Todavia, a África manteve-se como uma espécie de reserva cativa dos defensores de diagnósticos sobre diferenças de desenvolvimento baseados em causas naturais (biológicas ou mesológicas). Ademais, para piorar, ficou exposta às alegações explicativas dos crescentes adeptos de visões psicologizantes da história. Vejamos alguns exemplos de tudo isso. No começo da década de 1960, 
James Coleman, reconhecido pelos estadunidenses como um especialista de ponta em questões de indução ao desenvolvimento, escreveu muito caracteristicamente que

o isolamento da África, facilitado pela floresta do grande platô africano, é também responsável pela instabilidade e a vulnerabilidade das pequenas sociedades africanas tradicionais, porquanto a falta de contato direto, intenso e continuado com culturas extra-africanas, resultou na ausência dos efeitos estimulantes e enriquecedores da infusão cultural, particularmente no nível material (COLEMAN, 1969, p. 240).

Donde a conclusão previsível de que é necessário levar aos africanos modos de pensar e tecnologias que superem o tradicionalismo de suas mentalidades coletivas e o conformismo provocado pela relação estabelecida com o meio ambiente ou, como preferiam dizer outros, pelos efeitos negativos e pela reação mais negativa ainda ao processo de dominação colonial.

No final da década de 1950, Everett Hagen, outro sociólogo estadunidense igualmente especialista em problemas de desenvolvimento, adotando uma postura mais compreensiva e mais capaz de incorporar as dimensões históricas, afirmou:

os ocidentais, como estrangeiros, dominaram os povos nativos pela força. Em quase todas as colônias eles também destruíram a cultura nativa e violaram seus mais profundos valores éticos e morais. $O$ resultado de tal destruição e da aparente desesperança de rebelião foi criar incerteza emocional, que tem certamente dois efeitos relevantes. Primeiro, luta fortemente contra a aquisição de motivação para o êxito de uma visão de mundo favorável à iniciativa. Segundo, cria necessidade intensa de apego a antigos valores que, por si só, permanecem entre a vida e o caos, e daí emerge profunda antipatia inconsciente por novas ocupações e por novas funções econômicas introduzidas pelos estrangeiros (HAGEN, 1967, p. 34).

Em um rodapé visando esclarecer tais afirmativas, ele chegou ao ponto de dizer que,

os inconscientes bloqueios ao interesse por novas ocupações não são contraditórios com a imitação de certos valores culturais dos estrangeiros, como, por exemplo, seus esportes, suas roupas e muitas de suas atitudes. Pelo contrário, certos princípios de 
Psiquiatria sugerem que os dois modos de comportamento podem ser esperados ao esmo tempo (HAGEN, 1967, p. 34n).

Não é preciso procurar muito para encontrar, ainda hoje, provavelmente mais hoje do que no passado, esse tipo de diagnóstico circulando pelos meios acadêmicos, pela imprensa e pelas agências internacionais de promoção do desenvolvimento. Ele assevera, em resumo, que, não importa se pela geografia ou pela psicologia, os africanos, se largados por si mesmos, estão condenados ao atraso, ou seja, a não chegarem a parecer, a não ser por força de imitações problemáticas, com os ocidentais modernos. Hoje em dia, novos personagens participam do mercado de idéias, mas o diagnóstico e o remédio continuam praticamente os mesmos (p. ex., LANDES, 2003).

No que sobra desse artigo discuto brevemente a hipótese de que, em linhas gerais, as convicções mais íntimas dos intelectuais brasileiros independente da coloração ideológica e da filiação teórica - apontam para um sentimento de plena integração do país ao relato padrão da ascensão do Ocidente. Forjado no decorrer do século XIX, ele impregna profundamente as maneiras como concebemos o passado. Neste relato há muito pouco o que fazer com os africanos, a não ser descrever seu uso como mão-de-obra e assinalar que, em troca desse labor, o Ocidente transferiu-lhes valores, crenças, técnicas e modelos de comportamento para transformá-los em civilizados e dotar-lhes de uma História com h maiúsculo. Como escreveu, em princípios da década de 1950, a antropóloga francesa Denise Paulme,

...segundo um preconceito arraigado, os africanos não teriam tido
qualquer participação na obra geral da civilização. A África não teria
história. (...) Na realidade, a presumível barbárie dos africanos
resultava, sobretudo, do desprezo com que os europeus dos fins do
século XIX se aproximaram de populações que viviam há várias
gerações em estado de guerra e insegurança permanentes
(PAULME, 1977, p. 5).

Tais clichês demoraram muito tempo para enfraquecer e mais tempo ainda para serem parcialmente superados. De fato, ainda na primeira metade da década de 
1960, Hugh Trevor-Roper, na época professor de História Moderna da Universidade de Oxford, na Inglaterra, defendeu posições que se tornaram um monumento do etnocentrismo. Ele pronunciou a afirmativa mais citada, parafraseada e repudiada pelos pesquisadores de História da África desde então. Convém, por isso mesmo, reproduzi-la sem intermediários. Segundo ele,

...os universitários, seduzidos, como sempre, pelo ar progressista da moda jornalística, reclamam o ensino da história da África Negra. No futuro, talvez exista alguma história africana para ensinar. No presente, não há nenhuma, ou há muito pouca: apenas a história dos europeus em África. $O$ resto é escuridão profunda. [E, arrematando, observou:] foram as técnicas européias, os exemplos europeus, as idéias européias que libertaram o mundo não europeu do seu passado - da barbárie em África; de uma civilização muito mais velha, mais atrasada e mais majestosa, na Ásia; e a história do mundo, nos últimos cinco séculos, enquanto significativa, foi a história da Europa (TREVOR-ROPER, 1966, p. 9). ${ }^{2}$

Naqueles tempos imediatamente pós-coloniais, que presenciavam as lutas e os percalços iniciais dos novos Estados africanos em construção, não demoraram a chover contestações de todos os lados àquelas palavras. Seus críticos defenderam com veemência a tese de que qualquer conjunto de seres humanos, independente de onde estiver, tem história, mesmo que as fontes para contá-la não sejam aquelas que os ocidentais consideram as únicas fiáveis. Ademais, denunciaram o caráter neocolonialista desse tipo de opinião, sublinhando que a história do continente africano não é uma função ou uma nota de rodapé da história dos seus conquistadores, mas um processo dotado de características próprias e irredutíveis. (DAVIDSON, 1968 e 1974; IYE, 2009). Neste sentido, já em 1964, Geoffrey Barraclough, afirmava que havia uma forte tendência entre os políticos, jornalistas e acadêmicos europeus e americanos de explicar as causas das independências africanas remetendo quase que exclusivamente a influxos externos ao continente. A compreensão judiciosa daqueles processos perigava malograr por conta da entrada, pela porta dos fundos, de uma visão histórica colonialista. Disse, então, o historiador britânico:

\footnotetext{
2 Para constar, lembro que esse historiador, cuja competência nos estudos sobre a Europa Moderna jamais foi questionada, foi agraciado pela primeira-ministra Margaret Thatcher, em 1979, como reconhecimento aos serviços políticos e pedagógicos prestados ao Império Britânico, com o título de Baron Dacre of Glanton.
} 
Ninguém que estude as sucessivas fases no progresso dos movimentos nacionalistas na Ásia e na África pode seriamente duvidar da influência exercida pela prática e exemplo da política ocidental. Mas devemos ser cuidadosos quanto aos corolários a extrair desse fato, e especialmente cuidadosos antes de aceitarmos a conclusão, comum entre os comentaristas políticos ocidentais, de que o impacto da Europa foi o catalisador que provocou 0 ressurgimento da Ásia e da África (BARRACLOUGH, 1966, p. 184).

E prosseguiu:

Todos os movimentos nacionalistas, em ambos os continentes, derivaram uma grande parte de sua força motivadora de uma consciência de seu passado histórico antes da intrusão européia. Essa consciência pode, como em tão grande parte da história ocidental, incorporar bastantes elementos místicos; mas o apelo às antigas civilizações africanas do vale do Nilo, à cadeia de Estados que floresceram no Sudão medieval, aos heróicos reis como Mansa Mussa, ao imperador do Mali no século XIV e a notáveis pensadores como Ahmad Baba, que ensinou na universidade de Sankore, em Timbuktu, no século XVI, constitui um elemento vital no nacionalismo africano (BARRACLOUGH, 1966, p. 187).

No entanto, apesar das advertências incisivas, estamos muito longe de vermos escorrerem para o bueiro da História palavras como a de Trevor-Roper. Idéias como as dele empolgam vastos setores intelectuais e políticos contemporâneos. Principalmente os que apregoam essa mixórdia de darwinismo social, idolatria do mercado, racismo deslavado, conservadorismo político e ocidentalismo histérico que brotou dos governos reacionários e do projeto neoliberal das décadas de 1970 e 1980. Seja arrumando causas geográficas para o atraso sócio-econômico africano, seja lamentando o fim do colonialismo e do imperialismo, esses atores sociais e políticos são os arautos do que Pierre Bourdieu chamou de revolução neoconservadora. O notável sociólogo empregou o prefixo neo para indica que seus promotores já não pretendem "invocar um passado idealizado, através da exaltação da terra e do sangue, temas agrários, arcaicos". Trata-se, antes, de uma iniciativa que "converte em norma de todas as práticas e, portanto, em regras ideais, as regularidades reais do mundo econômico abandonado à sua própria lógica, a chamada lei de mercado, quer dizer, a lei do mais forte". (BOURDIEU, 2002, p. 29-30).

Note-se que esse conservadorismo radical não se resume à proposta de converter as leis do mercado em leis civis, como se elas bastassem para 
assegurar o funcionamento de uma sociedade. Ele tem outras facetas. Uma delas é a desqualificação da importância dos povos que teriam perdido a oportunidade de aderir - porque, presumidamente, não quiseram ou não souberam - às crenças, valores, objetivos, tipos de organização social e de ordem política apregoadas como os elementos essenciais que levaram os Estados do Ocidente a conduzirem a locomotiva da história. Tais povos teriam optado por serem meros vagões de passageiros sem vontade de dirigir suas próprias vidas. O corolário dessa perspectiva é a conclusão de que as trajetórias dos países que não escolheram a via ocidental só têm o que ensinar em chave negativa: nunca fazer como eles, que foram tontos o suficiente para não fazerem como nós. Assim, não admira que, até algumas décadas atrás, o passado das sociedades africanas mal recebesse o direito a ser mencionado em rodapé, mesmo em obras que tinham como objetivo pintar um panorama sintético da História Mundial. (p. ex., McNEILL, 1972; PIRENNE, 1973). Tampouco admira a lentidão, para não dizer a má vontade, com que os meios acadêmicos e escolares brasileiros se dispõem a tomar conhecimento e a levar a sério os projetos de superação dessa situação política e intelectualmente lastimável.

Escrevo estas páginas oito anos depois que a lei 10.639 foi assinada. Ao longo desse período, a considerar por um passar d'olhos que realizei sobre as grades curriculares de cursos de História espalhados pelas várias regiões do país, não foram poucas as instituições universitárias que criaram disciplinas relacionadas à História da África. Essa é uma notícia auspiciosa, mas devemos continuar precavidos e evitar o entusiasmo acrítico. Em muitos casos, pelo que pude perceber, a matéria está organizada de maneira excessivamente subserviente aos termos da legislação. Tanto assim que há cursos nos quais a ementa da disciplina corresponde literalmente ao que está estabelecido no parágrafo primeiro da lei mencionada, ou seja, que os conteúdos do ensino de História e Cultura Afro-Brasileira devem incluir

o estudo da História da África e dos Africanos, a luta dos negros no Brasil, a cultura negra brasileira e o negro na formação da sociedade nacional, resgatando a contribuição do povo negro nas áreas social, econômica e política pertinentes à História do Brasil (apud SILVA, 2010, p. 19). 
Tudo leva a crer que não ocorreu nessas instituições uma avaliação criteriosa do que reza o diploma legal. Aceitou-se o que está dito e pronto. Um indicador indireto do que estou afirmando são as entradas de livros pertinentes nas bibliotecas das universidades e faculdades. Como acontece com as demais disciplinas, pode ser que a grande maioria dos professores esteja usando materiais pessoais e fornecendo fotocópias a seus alunos, o que distorce uma análise dos recursos didáticos baseada apenas nos catálogos online das bibliotecas. Mesmo assim, pode-se deduzir que não há um estímulo à pesquisa por conta própria dos alunos e que os livros relacionados nas bibliografias não estão disponíveis plenamente. Meu ligeiro passar d'olhos também mostrou que, neste momento, a maioria das instituições de ensino continua ignorando solenemente a nova demanda. É bem provável que nelas prevaleça a mentalidade que venho comentando. Porém, não se pode descartar a possibilidade de que, em algumas delas, seja realmente verdadeira a justificativa mais generalizada e mais duvidosa de todas: a falta de docentes e de materiais didáticos. Digo duvidosa por uma razão muito simples: se não há professores para ministrar conteúdos de História da África - por extensão: pessoas capazes de organizar bibliografias básicas e produzir programas introdutórios - é porque vigora um poderoso ocidentocentrismo. Em resumo: um círculo vicioso.

Não perscrutei de modo metodologicamente rigoroso os programas das disciplinas História da África e História e Cultura Afro-Brasileira que pude obter. Apenas li e fiz anotações rápidas. Mas, vou arriscar e enumerar ao menos dois dos elementos que se combinam para dar o perfil do que, na minha opinião, predomina hoje em dia nessa área. O primeiro é o caráter, por assim dizer, instrumental do ensino de História da África. Ela aparece em função da História do Brasil e não como um objeto historiográfico em si mesmo. Isso se expressa, por exemplo, na concentração dos itens programáticos e das indicações bibliográficas no período de vigência do tráfico negreiro no Atlântico. Penso, ao contrário, que os povos e civilizações da África merecem a atenção dos brasileiros não somente porque são os ancestrais dos negros que para cá vieram, mas também porque têm muita coisa a ensinar aos seres humanos daqui, de lá e d'acolá. A experiência da Humanidade é vasta e longa. Apesar do que gostam de crer os eurocêntricos empedernidos, não há um ponto privilegiado para onde se 
deve olhar a fim de se começar a falar dessa experiência. Uma história global bem contada pode começar numa aldeia africana, num porto da Oceania ou no centro de Paris. Afinal, o Globo é grande e redondo. Cabe, no fundo, mudar o eixo do relato histórico dominante nas escolas. Preocupar-se mais com o desenvolvimento de habilidades cognitivas do que com a ideologia historiográfica de forte sabor colonialista que é a narrativa da ascensão do Ocidente.

O segundo elemento que me parece importante acentuar é a preocupação em enfatizar aspectos da História da África que guardem alguma semelhança com aspectos da História do Ocidente. Essa questão precisa ser judiciosamente discutida. Compreende-se que, diante das cascatas de desqualificações dos povos africanos, os historiadores anti-imperialistas e anti-negacionistas procurem mostrar que eles também construíram monumentos extraordinários, desenvolveram tecnologias profundamente criativas, formaram complexos urbanos e edificaram impérios. Compreende-se, igualmente, a iniciativa crítica de numerosos intelectuais africanos que, principalmente nos anos de luta pela formação dos novos Estados do continente, mostraram os logros do passado, ao mesmo tempo em que denunciavam as mistificações colonialistas que nada atribuíam de valor aos povos da África (p. ex., DIOP, 1968; tb. KI-ZERBO, 2006). Assim, com grande freqüência, as menções aos reinos e impérios do Sudão Ocidental e do vale do Nilo vinham acompanhadas de comparações com a Europa Medieval, que normalmente saia perdendo (DAVIDSON, 1980; RODNEY, 1975). Na maioria das vezes, tais comparações tinham por meta mais o estímulo de uma espécie de orgulho identitário entre os afro-descendentes do que o estabelecimento de uma temática para o efetivo exercício do estudo histórico. Tenha ou não clareza a esse respeito, toda vez que alguém subordina o relato histórico à suas potenciais funções terapêuticas (o fortalecimento do sentimento de identidade, a redução das frustrações, o combate aos clichês autodepreciativos) gera profundas implicações políticas e epistemológicas. Por suposto, pode-se enaltecer - como fazem os historiadores de outros povos com seus heróis - os feitos dos governantes dos reinos imperiais do Sudão Ocidental, do Egito, da Núbia e do Grande Zimbábue, essa maravilha arquitetônica que historiadores e arqueólogos europeus negaram por muito tempo que tivesse origens autenticamente africanas. Mas, o que não se deveria fazer é obscurecer, 
em nome do resgate da autoestima ou do combate à ideologia colonialista, o fato de que, entre outras coisas, eles compunham a elite dirigente de sociedades que pouco ficavam a dever aos europeus feudais ou escravocratas em matéria de exploração do trabalho e de cobrança escorchante de tributos (READER, 2004; M’BOKOLO, 2009).

Em suma: como qualquer história, a dos africanos é mais uma das facetas plurais da experiência da Humanidade como um todo. Ela tem suas particularidades, mas isso não quer dizer que seja absolutamente impermeável ou incomparável. Na realidade, tudo vai depender da postura teórica e política de quem a estuda, pois ela tanto pode ser vista como um planetário de excepcionalidades quanto como um feixe de processos que não diferem substantivamente das histórias dos demais povos do Globo. Defendo essa segunda perspectiva. Não creio, obviamente, que devemos deixar de lado o interesse intrínseco das singularidades. Uma história que nada tenha de próprio nada tem a nos dizer. Não acho, também, que o horizonte identitário fornecido pela historiografia produzida pelo nacionalismo pan-africanista deva ser reproduzido sem mitigações. Se ele foi fundamental na mobilização de corações e mentes para o combate em todas as frentes contra o imperialismo, seus resultados em termos de conhecimento histórico deixam muito a desejar, especialmente quando, em nome da unidade de propósitos, favorecem uma visão unificadora e simplificadora de um continente tão vasto e diversificado.

Ademais, penso que é preciso encarar abertamente processos e fenômenos que, ainda hoje, tendem a ser sublimados em nome da bandeira anticolonialista. Refiro-me a questões relacionadas às formas de estratificação social, às condutas das elites dirigentes, aos tipos de escravidão, aos sacrifícios humanos, às relações gerontocráticas e machocêntricas de dominação e assim por diante. Felizmente, ainda que aos poucos, o cenário está mudando. Há um número crescente de pessoas defendendo uma renovação do ensino e da escrita da história a partir da noção de Globalização, o que implica produzir ações didático-pedagógicas preocupadas em traçar um panorama mais equilibrado dos 
diversos continentes. Isso afeta diretamente o modo de considerar a África, embora não assegure de antemão que ela será vista de uma forma bem diferente daquela que tem predominado. Para se conseguir alcançar um patamar efetivamente novo é preciso ampliar o leque de alianças políticas e didáticopedagógicas e fazer o possível para tornar a História da África a coisa mais normal do mundo nas escolas e universidades brasileiras. O que não podemos é dar trégua à estupidez.

\section{Referências}

ACAYABA, C.; REIS, T. Colégios ignoram lei que obriga ensino da cultura afro. Folha de S. Paulo, 27/10/2008.

ALENCASTRO, L. F. de. Para historiador, continente africano é depreciado. Folha de S. Paulo, 05/09/2001.

ATHAYDE, J. L. de. Importância da história da África Negra. Afro-Ásia, 1965, p. 57 e ss.

BARRACLOUGH, G.. Introdução à História Contemporânea. Rio: Zahar, 1966.

BOURDIEU, P. Pensamiento y Acción. Buenos Aires: Libros del Zorzal, 2002.

COLEMAN, J. A política da África Subsaariana. In: ALMOND, G.; COLEMAN, J. (Coord.). A Política das Áreas em Desenvolvimento. Rio: USAID/Freitas Bastos, 1969, p. 239-250.

DAVIDSON, B. Revelando a Velha África. Lisboa: Prelo, 1968.

. Los Reinos Africanos. New York: Time-Life, 1974.

. A Descoberta do Passado de África. Lisboa: Sá da Costa, 1980.

DIOP, C. A. Contribuciones culturales de Africa y sus pespectivas. In: KOHN, H. y SOKOLSKY, W. El Nacionalismo Africano en el Siglo XX. Buenos Aires: Paidós, 1968, p. 174-184.

FALCON, F. et alli. História. Rio: Francisco Alves/Edutel, 1977.

FREITAS, D. África e Brasil. Folha de S. Paulo, 05/01/1982, p. 3.

HAGEN, E. O processo de mudança. In: DURAND, J. C. G. (Org.). Sociologia do Desenvolvimento. Rio: Zahar, 1967, p. 27-40.

HARRISON, L. e HUNTINGTON, S. (Org.). A Cultura Importa: os valores que definem o progresso humano. Rio: Record, 2002.

IYE, A. M. Descolonizar a la historia. El Correo de la UNESCO. n.8, 2009, p. 8-10. KI-ZERBO, J. Para Quando a África? Rio: Pallas, 2006.

KLARE, M. T. Guerras por los Recursos. Barcelona: Urano, 2003. 
LANDES, D. A Riqueza e a Pobreza das Nações. Rio: Elsevier, 2003.

LIMA, I. M. Ensino de história da África no Brasil: caminhos e descaminhos de uma luta contra o racismo velado. Revista Novas Idéias. Recife, v.1, n.1, jan/jun de 2008, p. 53-74.

M’BOKOLO, E. África Negra: História e Civilizações. Volume I. Salvador/São Paulo: EDUFBA/Casa das Áfricas, 2009,

McNEILL, W. H. História Universal. Porto Alegre/São Paulo: Globo/Edusp, 1972.

MERCIER, P. História da Antropologia. Rio: Eldorado, 1974.

MOURA, C. Sociologia do Negro Brasileiro. São Paulo: Ática, 1988.

PAULME, D. As Civilizações Africanas. Lisboa: Europa-América, 1977.

PELEGRINI, S.;ç ALVES, A. P.. Eu quero um homem de cor. Revista de História da Biblioteca Nacional. v. 6, n.67, abril de 2011, p. 44-47.

PIRENNE, J-H. Panorama da História Universal. São Paulo: Difel/Edusp, 1973.

POIRIER, J. História da Etnologia. São Paulo: Cultrix, 1981.

READER, J. África: Biografia de um Continente. Lisboa: Europa-América, 2004.

ROCHA, L. C. P. da. Política educacional e a Lei 10.639/03: Uma reflexão sobre a necessidade de superação de mecanismos ideológicos legitimadores do quadro de desigualdades raciais e sociais na sociedade brasileira. In: COSTA, H.; SILVA, P. V. B. da (Org.). Notas de História e Cultura Afro-Brasileiras. Ponta Grossa: Editora UEPG/UFPR, 2007, pp. 25-37.

RODNEY, W. Como a Europa Subdesenvolveu a África. Lisboa: Seara Nova, 1975. RODRIGUES, J. C. Pequena História da África Negra. São Paulo/Brasília: Globo/ SCPR-Biblioteca Nacional, 1990.

ROMERO, E. O. Africa: Pasado y Presente. Santiago-Chile: Quimantu, 1972.

SILVA, E. J. da. Lei no 10.639/2003; perspectivas e possibilidades de aplicação na escola. In: COSTA, L. G. (Org.). História e Cultura Afro-Brasileira: Subsídios Para a Prática da Educação Sobre Relações Étnico-Raciais. Maringá: Eduem, 2010, p. 13-38.

SILVA, P. V. B. da; COSTA, H. e MINDAL, C. B.. NEAB-UFPR e a formação continuada em História e Cultura Afro-Brasileiras: Notas Introdutórias. In: COSTA, H. e SILVA, P. V. B. da (Org.). Notas de História e Cultura AfroBrasileiras. Ponta Grossa: Editora UEPG/UFPR, 2007, p. 11-24.

TOYNBEE, A. Estudio de la Historia (comp. D. C. Somervell). Volume I. Buenos Aires: Emecé, 1959,

TREVOR-ROPER, H. A Formação da Europa Cristã. Lisboa: Verbo, 1966.

Recebido em 14 de janeiro de 2013. Aprovado em 21 de julho de 2014. 